\title{
Renewable energy sources in maintaining environmental stability on the Black Sea coast
}

\author{
Mzia Diasamidze ${ }^{1 *}$, Ana Shotadze $^{1}$ \\ ${ }^{1}$ Faculty of Navigation, Batumi State Maritime Academy, Rustaveli Avenue 53, 6000, Batumi, Georgia
}

\begin{abstract}
The aim of this research is to study the main ecological parameters of the Black Sea in an experimental way as well as to evaluate the results and to draw conclusions. We aim at determining the cause of pollution of the sea area represented by the emissions from ships' engines and pollution by surface waters. Our empirical part that included the field expeditions, sampling was carried out with the involvement of students within the framework of the internal grant research project "Monitoring of the Black Sea Ecological Status - Sea Water Quality Survey". We studied the level of pollution of two rivers flowing into the Black Sea, Bartskhana and Kubistskali, and made relevant conclusions about the types of pollution, proper measurements and causal relationship of the causes of sea water pollution with the vessels entering the port of Batumi.
\end{abstract}

\section{Introduction}

Numerous studies have been devoted to the study of the ecological status of the Black Sea $[1,2]$. As the economy and transport infrastructure of the Black Sea Basin countries grow, the research problem is constantly changing [3]. With it, the degree of pollution of the marine environment also increases. The most important ecological problem is the introduction of large amounts of biogenic substances, various pollutants (pesticides, phenols, resins, etc.) by rivers into the sea. Increased maritime traffic is another factor in marine pollution. In previous studies we have explored issues about ballast waters.

In particular, the issues of pollution of the marine environment by ships with ballast waters [4]. At this point we have evaluated the results of previous studies. The limited circulation of Black Sea water to the ocean prevents the removal of pollutants into the marine environment, resulting in intensified accumulation processes. Therefore, the coastline is under strong anthropogenic load [5]. The Black Sea represents the greatest resource potential, the recreation area and the main artery of foreign relations. Therefore, the scientific study of ecological issues of the Black Sea and its prediction is highly relevant and gaining a global scale.

\footnotetext{
* Corresponding author: m.diasamide@bsma.edu.ge
} 
Together with the maritime academy students, we explored the use of wind as a renewable energy in the form of wind turbines on ships. The use of these types of turbines will significantly improve the ecological safety of the marine environment [6].

\section{Materials and methods}

There are three main rivers in the area of Batumi Oil Terminal Ltd., which flow in the direction of the Black Sea: Korolistskali, Kubistskali and Bartskhana river. Of these three rivers, the Korolistskali river is less polluted with oil products, the other two rivers are more polluted, as the Bartskhana and the rivers. Kubistskali will pass through almost all zones of the terminal. It should be noted that the background pollution of the Bartskhani river with oil products is quite high, which is caused by the historical pollution of the areas occupied by the Batumi Oil Depot Ltd. Of course, the pollution of rivers also leads to the disturbance of the ecological condition of the Black Sea. Therefore, the purpose of the first phase of fieldexpedition studies was to identify the main rivers joining the sea and its surrounding areas. The subject of the second stage field-scientific research was the study of the ecological parameters of the sea in the selected areas in the Batumi water area (see Figure 1).
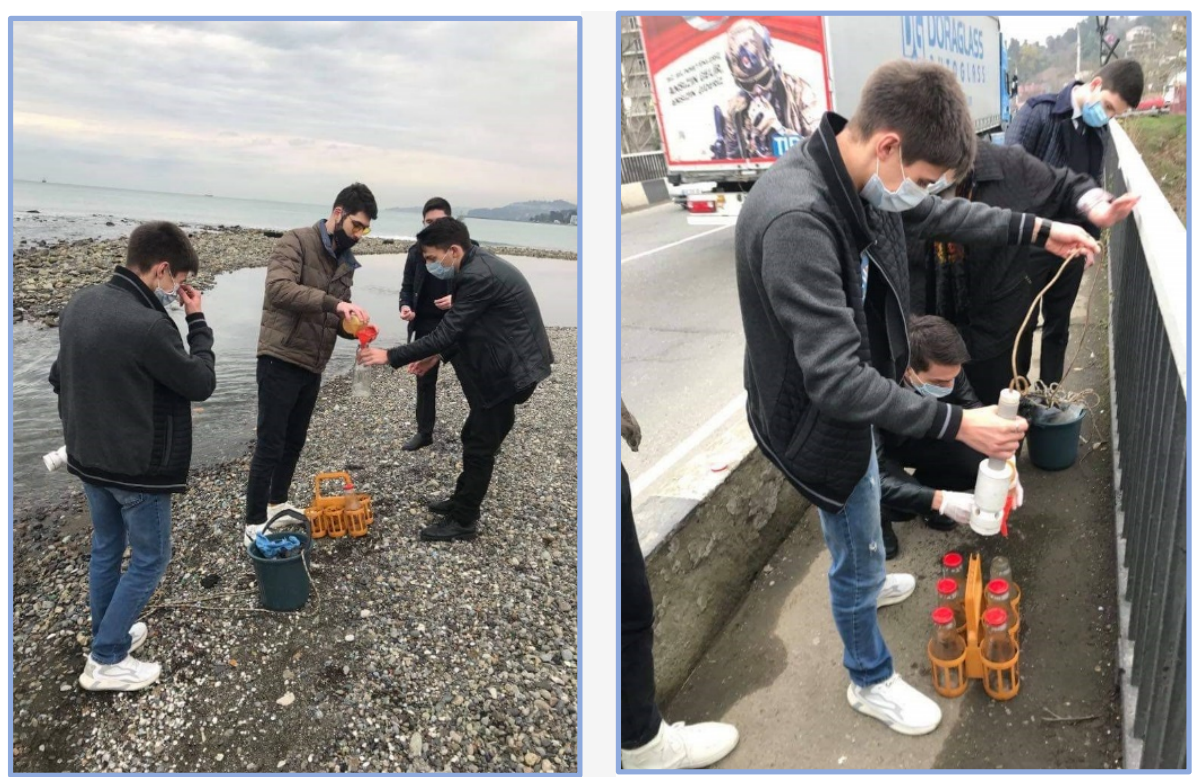

Fig. 1. Examples of field research at the Black Sea site

Maintaining and protecting the ecological condition of the Black Sea coastline and its surrounding areas is recognized by all its neighbouring states as a priority [7]. The rivers flowing into the Black Sea from Georgia along the Batumi coast are used by the population for household and agricultural purposes (see the map of the area at Figure 2 that follows below). Therefore, the sources of water pollution are also related to such activities of the population.

The most common pollutants in water bodies are: pesticides, fertilizers, petroleum products, heavy metals, various substances produced by chemical and industrial processes, improper treatment facilities and others. In order to check the water quality of the Batumi 
water area, samples were taken in the inland waters of Batumi, which were subjected to laboratory research, water pollution indicators were determined [8].

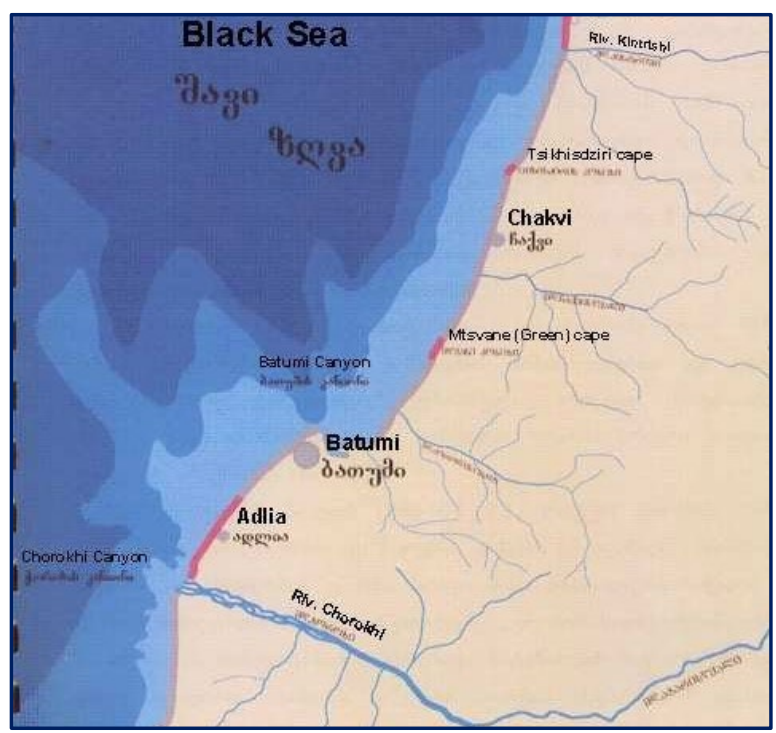

Fig. 2. Map of Batumi Black Sea coast

In this study we used the following research instruments: Spectro-photometer (DR 3900), electronic scale, portable laboratory device MULTI 3440 SET F (with three electrodes - to measure salinity, dissolved oxygen and $\mathrm{pH}$ ), COD REACTOR - to determine the chemical oxygen demand in water, and $\mathrm{pH}$. COD - to determine the number of inorganic pollutants found in surface waters (rivers). Getting to know the properties of water begins with determining its organoleptic parameters - water colour, transparency, taste and weight of the substance. Getting to know the properties of water begins with determining its organoleptic parameters - water colour, transparency, taste and weight of the substance. The ecological condition of the sea also depends on the amount of oxygen in the water (\%), salinity (TDS), the concentration of hydrogen ions in the Black Sea water $(\mathrm{pH})$, the study of the amount of oxygen (J.M. and J.M.). We have studied water pollution with pesticides - as a widespread problem, as pesticides are still actively used in agriculture. Getting large amounts of fertilizers into reservoirs leads to the accumulation of extra phosphorus and nitrogen which often leads to eutrophication.

In the area of Batumi water area, mainly three rivers flow in the direction of the Black Sea: Korolistskali, Kubistskali, and Bartskhana. Naturally, the pollution of rivers also leads to the disturbance of the ecological condition of the Black Sea. Therefore, the purpose of Phase I field-expedition studies was to identify the main rivers joining the sea and its surrounding areas. The subject of the II stage field-scientific research was the study of the ecological parameters of the sea in the selected areas in the Batumi water area. For this purpose, we carried out water samples at the sensitive areas of the coastline. We studied the ecological characteristics of the Bartskhani and Kubistskali rivers periodically for two months, observing the changes in the given ecosystem during the months of April-October. 


\section{Practical results}

The study was performed using inpatient and laboratory methods (see Figure 2). We compared the measurement results with the parameters defined by the norm. The results of the laboratory study of water samples taken from rivers according to seven parameters are given in Tables 1, 2, and 3.

Table 1. Data for April, 2020

\begin{tabular}{|c|c|c|c|c|c|c|}
\hline \multicolumn{7}{|c|}{ I Field Survey Results } \\
\hline$\underset{\mathrm{mg} / \mathrm{l}}{\text { Ammonia }}$ & $\begin{array}{l}\text { BOD } \\
\mathrm{mg} / \mathrm{l}\end{array}$ & $\begin{array}{c}\text { Nitrates } \\
\text { mg / l }\end{array}$ & $\begin{array}{c}\text { Nitrites, } \\
\text { mg / l }\end{array}$ & $\begin{array}{c}\text { Phosphorus } \\
\text { mg / I }\end{array}$ & $\begin{array}{l}\text { COD } \\
\mathrm{mg} / \mathrm{l}\end{array}$ & $\begin{array}{c}\text { suspended } \\
\text { matter } \\
\text { mg / l }\end{array}$ \\
\hline 1 & 2 & 3 & 4 & 5 & 6 & 7 \\
\hline \multicolumn{7}{|c|}{ River "Bartskhana" } \\
\hline $0,8-0,87$ & $1,28-2,5$ & $0,3-0,48$ & $0,7-0,81$ & $0,06-0,075$ & 28,5 & 0,75 \\
\hline \multicolumn{7}{|c|}{ River "Kubistskali" } \\
\hline 1 & 2 & 3 & 4 & 5 & 6 & 7 \\
\hline $0,11-0,17$ & $2,1-2,9$ & $1,3-1,8$ & $0,75-0,89$ & $0,17-0,2$ & 27,16 & 0,68 \\
\hline \multicolumn{7}{|c|}{ Compared to the norm } \\
\hline 0,39 & $4<\ldots>6$ & 40 & 0,08 & 2 & $25-100$ & up to 50 \\
\hline
\end{tabular}

Table 2. Data for July, 2020

\begin{tabular}{|c|c|c|c|c|c|c|}
\hline \multicolumn{7}{|c|}{ II Field Survey Results } \\
\hline $\begin{array}{c}\text { Ammonia } \\
\mathrm{mg} / \mathrm{l}\end{array}$ & $\begin{array}{l}\text { BOD } \\
\mathrm{mg} / \mathrm{l}\end{array}$ & $\begin{array}{c}\text { Nitrates } \\
\text { mg / l }\end{array}$ & $\begin{array}{c}\text { Nitrites, } \\
\text { mg / l }\end{array}$ & $\begin{array}{c}\text { Phosphoru } \\
\text { s } \\
\text { mg / l }\end{array}$ & $\begin{array}{l}\text { COD } \\
\mathrm{mg} / \mathrm{l}\end{array}$ & $\begin{array}{c}\text { suspended } \\
\text { matter } \\
\text { mg / I }\end{array}$ \\
\hline 1 & 2 & 3 & 4 & 5 & 6 & 7 \\
\hline \multicolumn{7}{|c|}{ River "Bartskhana" } \\
\hline 0,4 & $\begin{array}{c}1,98- \\
2,1\end{array}$ & $\begin{array}{c}0,17- \\
0,19\end{array}$ & $0,31-0,45$ & $0,6-0,8$ & 25 & Not fixed \\
\hline \multicolumn{7}{|c|}{ River "Kubistskali" } \\
\hline 1 & 2 & 3 & 4 & 5 & 6 & 7 \\
\hline $0,09-0,4$ & $\begin{array}{l}1,0- \\
1,74\end{array}$ & $0,1-0,7$ & $\begin{array}{c}\text { Ammonium } \\
\text { nitrogen } \\
0,3-0,41\end{array}$ & Not fixed & 27,0 & 0,81 \\
\hline \multicolumn{7}{|c|}{ Compared to the norm } \\
\hline 0,39 & $4<\ldots>6$ & 40 & 0,08 & 2 & $25-100$ & up to 50 \\
\hline
\end{tabular}

Table 3. Data for October, 2020

\begin{tabular}{|c|c|c|c|c|c|c|}
\hline \multicolumn{7}{|c|}{ III Field Survey Results } \\
\hline $\begin{array}{c}\text { Ammo } \\
\text { nia mg } \\
/ / 1\end{array}$ & $\begin{array}{l}\text { BOD } \\
\mathrm{mg} / \mathrm{l}\end{array}$ & $\begin{array}{c}\text { Nitrates } \\
\text { mg / l }\end{array}$ & $\begin{array}{c}\text { Nitrites, } \\
\text { mg / I }\end{array}$ & $\begin{array}{c}\text { Phosphorus } \\
\text { mg / l }\end{array}$ & $\begin{array}{l}\text { COD } \\
\mathrm{mg} / \mathrm{l}\end{array}$ & $\begin{array}{c}\text { suspended } \\
\text { matter } \\
\text { mg / l }\end{array}$ \\
\hline 1 & 2 & 3 & 4 & 5 & 6 & 7 \\
\hline \multicolumn{7}{|c|}{ River Bartskhana } \\
\hline $\begin{array}{c}0,72- \\
1,35\end{array}$ & $\begin{array}{l}0,67- \\
4,37\end{array}$ & $0,24-0,28$ & $0,4-0,65$ & $0,3-0,47$ & 26,7 & Not fixed \\
\hline \multicolumn{7}{|c|}{ River Kubistskali } \\
\hline 1 & 2 & 3 & 4 & 5 & 6 & 7 \\
\hline $\begin{array}{c}0,42- \\
0,53\end{array}$ & $1,98-2,1$ & $0,12-0,182$ & Not fixed & Not fixed & 24,3 & 0,67 \\
\hline \multicolumn{7}{|c|}{ Compared to the norm } \\
\hline 0,39 & $4<\ldots>6$ & 40 & 0,08 & 2 & $25-100$ & up to 50 \\
\hline
\end{tabular}


As a result of primary and repeated inspection of sea water and river-sea tributaries on oil products of Batumi coast, the average salinity index was TDS $=17.0-20.0 \%$. As for the content of nitrates, nitrites and ammonia, it was observed only in two areas - in the water area of the port of Batumi and in the sea near Ardagan Lake (Figure 3).

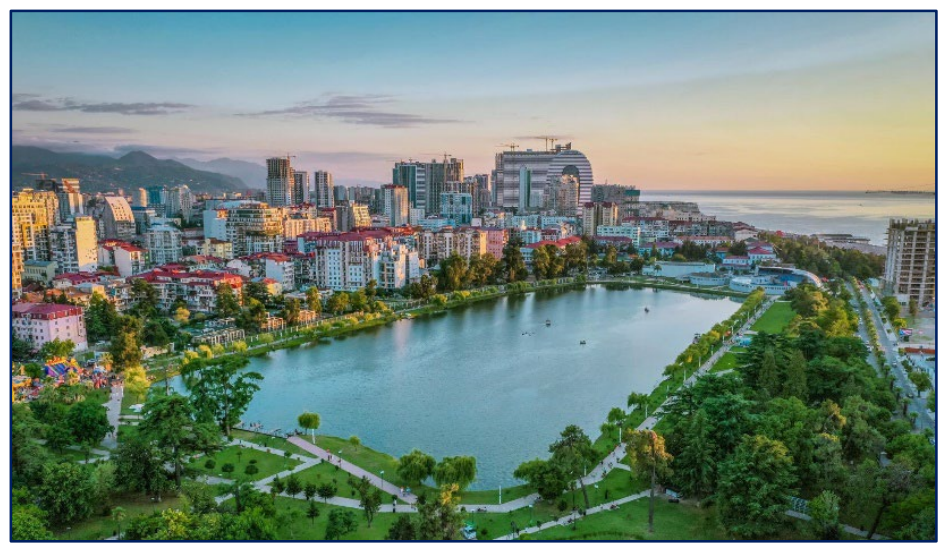

Fig. 3. Ardagan Lake

The results are shown in Table 4.

Table 4: Data for August, 2020

\begin{tabular}{|c|c|c|c|}
\hline sampling points & nitrates & Nitrites & Ammonia \\
\hline Batumi port water area & $0,11 \mathrm{mg} / 1$ & $0,2 \mathrm{mg} / 1$ & $0,4 \mathrm{mg} / 1$ \\
\hline The sea strip nearby Lake Ardagan & $0,35 \mathrm{mg} / 1$ & - & $1,2 \mathrm{mg} / 1$ \\
\hline assessment & Within Norm. & Within Norm. & Within Norm. \\
\hline
\end{tabular}

Thus, the results of our research allowed us to determine the nature of the change in the ecological parameters of the Black Sea Batumi water area. These results are very important for fostering sustainable development and helping to promote the renewable energy sources in this very region. In particular, we found and determined that the pollution of the Batumi coastline is probably related to the pollution with drainage water. It is noteworthy that by using these indicators in practice, it is possible to assess the ecological safety of the Batumi port optimally.

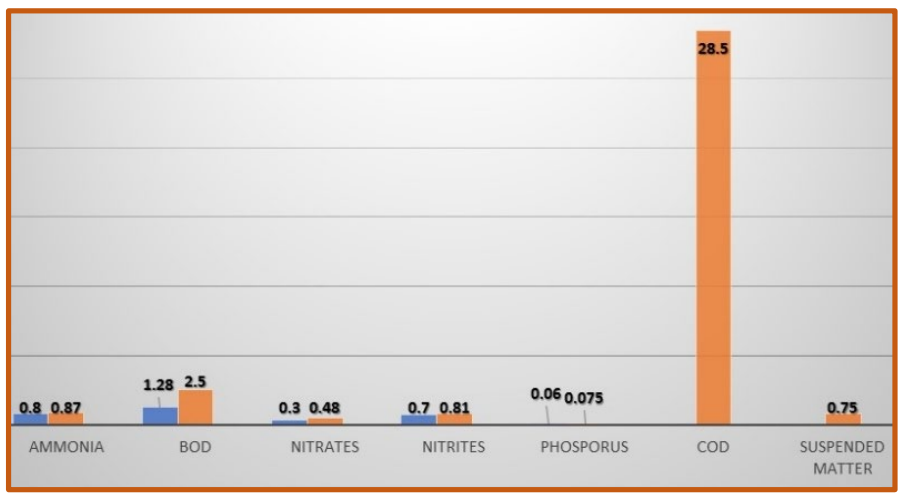

Fig. 4. Results for river Bartskhana 


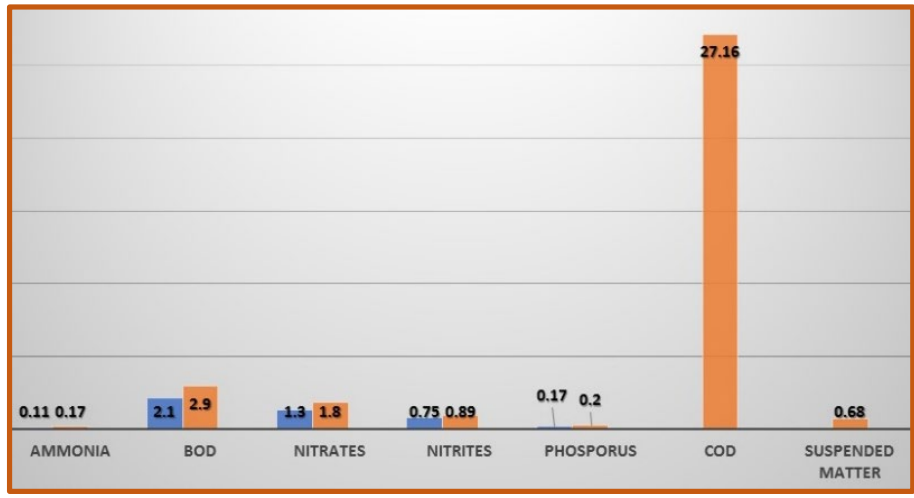

Fig. 5. Results for river Kubistskali

The parts of experimental studies were analyzed separately for the rivers Bartskhan and Kubistskali, the results are presented in diagrams (see Figures 4 and 5).

\section{Conclusion and recommendations}

In the conclusions, we want to state that after processing the research results and comparing the obtained data with the normalized parameters, we made the important conclusions: First, our field-scientific studies conducted on the rivers "Bartskhana" and "Kubistskali" identified sensitive areas, where the process of taking analytical samples and laboratory tests (according to seven parameters) was carried out for 6 months.

Second, seawater analyses were taken at sensitive points of the Black Sea (mainly at river confluences, coastline points), the concentration of seawater hydrogen ions and the quantitative salinity were determined in laboratory conditions - on average, 17-20\%;

Third, laboratory studies have shown that the concentration of hydrogen ions in the confluence of the rivers "Bartskhana" and "Kubistskali", as well as in the water area of the port of Batumi varied in the range of $\mathrm{pH}=6.5-8.3$. This figure should be taken into account in the complex study of ecological parameters in the Black Sea coast;

Fourth, laboratory conditions of Black Sea ammonia (partial excess), nitrates (low rate), nitrites (excess) and phosphorus (within the norm) were determined. Which leads us to the conclusion that in these rivers there have sometimes been discharges of fertilizers at such concentrations that their natural decontamination can no longer take place and the ecosystem is being polluted.

Fifth, researched by BOD and COD Result - the rate is within the norm. Weighted particles were not observed;

The obtained results allow us to comprehensively assess the modern ecological problems of the Black Sea and to plan ecological security measures for its coastline and surrounding areas.

All in all, we have studied issues about ballast waters. In particular, the issues of pollution of the marine environment by ships with ballast waters We have come to the conclusion that one of the most reliable ways to reduce environmental pollution from ships is to use renewable energy on ships. It is true that this source of energy cannot fully provide energy in long-distance sailing, but their use on small tonnage ships would give good results. Moreover, the leading countries of the world, including Georgia, have the practice of producing and using wind energy [9]. 
The high interest shown by students gives us the incentive and interest to continue research in this direction, thus promoting on the one hand the involvement of students in research activities, On the other hand, we develop and apply the inner culture, morality and knowledge of the student-youth to the realization that the preservation of the ecosystem of nature depends in large part on their right actions [10] .

\section{References}

1. L. Rusu, D. Ganea, E. Mereuta, Energy Exploration \& Exploitation, 36(2), 335-351 (2018)

2. T. Oguz, Frontiers in Marine Science, 4, 110 (2017)

3. B. Levent, A. Öztekin, F. Şahin, U. Arici, U. Özsandikçi, Mediterranean Fisheries and Aquaculture Research, 1(2), 66-86 (2018)

4. D. Onwuegbuchunam, T. Ebe, L. Okoroji, A. Essien, Journal of Marine Science and Engineering, 5(3), 39 (2017)

5. Ton H. Snelder, Scott T. Larned \& Rich W. McDowell, New Zealand Journal of Marine and Freshwater Research, 52(3), 336-361 (2017)

6. G.Surmanidze, M.Diasamidze, IAMU 2017, 3 (2017)

7. M. I. Nenciu, V. Nita, A. Totoiu, H. Hamza, Journal of Environmental Protection and Ecology, 21(1), 184-192 (2020)

8. J.F. Pons Austina, http://hdl.handle.net/10251/54792 (2014)

9. M.Diasamidze, I.Takidze, Innovative Economics and Management, 4, 297-302 (2017)

10. M.Diasamidze, A.Shotadze, Fundamental and applied researches in practice of leading scientific schools, 31(1), 58-60 (2019) 